\title{
Comparative Study Between Chicken Gizzards and Beef as Diets and its Influences on the Post- Embryonic Development and Longevity of Chrysomya megacephala (Fabricius) (Diptera: Calliphoridae)
}

\author{
Daniele Lourinho Dallavecchia ${ }^{\bowtie}$, Adriana Cristina Pedroso Ferraz ${ }^{1}$, \\ Gustavo Silva de Miranda², Alexandre Sousa da Silva ${ }^{3}$ \& Valéria Magalhães-de-Aguiar ${ }^{1}$
}

1. Instituto de Biociências - CCBS - Unirio, Laboratório de Estudo de Dípteros, e-mail: danieledallavecchia@gmail.com (Autor para correspondência ${ }^{凶}$ ), adrianapedroso7@gmail.com, valerialed@yahoo.com.br. 2. Københavns Universitet (University of Copenhagen), e-mail: gustavo_mir5@hotmail.com. 3. Departamento de Matemática e Estatística Unirio, e-mail: alexandre.silva@uniriotec.br.

\section{EntomoBrasilis 8 (1): 17-23 (2015)}

Abstract. Chicken gizzard was tested as an alternative to beef diet for creating Chrysomya megacephala (Fabricius) to reduce costs and optimize the time of diet preparation and maintenance of the colony diet. Forty newly hatched larvae were placed in 100 grams of diet: gizzard and meat (control). The experiment was performed in triplicate. The mass of mature larvae was recorded in semi-analytical balance and separate batch of five. After emergence, three replicates of 10 pairs of adults were formed. The post-embryonic development was evaluated by Tukey's test at a $5 \%$ level of significance and longevity was adjusted Weibull regression. The mass of mature larvae showed no significant difference. The larval stage of flies reared in meat was longer. Pupae and newly emerged adults showed no significant differences as a function of diet. The increased mortality rate after after 22 days in both experimental diets. Greater longevity was achieved with diet gizzard, which was more efficient than the meat on the biological parameters studied.

Keywords: Biodiversity; Ecology; Entomology; Natural Diet; Reproduction.

\section{Estudo Comparativo entre a Moela de Frango e Carne Bovina como Dietas e suas Influências sobre o Desenvolvimento Pós-Embrionário e Longevidade de Chrysomya megacephala (Fabricius) (Diptera: Calliphoridae)}

Resumo. Moela de Frango foi testada como dieta alternativa à carne para criação de Chrysomya megacephala (Fabricius) visando reduzir custos e otimizar o tempo de preparação da dieta e manutenção da colônia. Quarenta larvas recém eclodidas foram colocadas em 100 gramas de dieta: moela e carne (controle). O experimento foi realizado em triplicata. A massa das lavas maduras foi registrada em balança semi-analítica e separada em lotes de cinco. Após a emergência, foram formadas três repetições de 10 pares de insetos adultos. O Desenvolvimento pós-embrionário foi avaliado pelo teste Tukey com nível a 5\% de significância e a longevidade foi ajustada por regressão Weibull. A massa das lavas maduras não apresentou diferença significativa. A fase larval de moscas criadas em carne foi mais longa. Pupa e adultos recém-emergidos não apresentaram diferenças significativas em função da dieta. A mortalidade aumentou após 22 dias de experimento em ambas as dietas. Uma maior longevidade foi conseguida com a dieta moela, que se mostrou mais eficiente do que a carne sobre os parâmetros biológicos estudados.

Palavras-Chave: Biodiversidade; Dieta Natural; Ecologia; Entomologia; Reprodução.

J nterest in the laboratory breeding of diptera is on the rise due to the applicability of this specific group of insects in biological pest control (CRISTINo et al. 2010), maggot debridement therapy (ShERMAn 2009), forensic entomology (EsTRADA et al. 2009; Ferraz et al. 2012) and in other areas of science. The implementation of biological control using microhymenoptera requires large stocks of pupae of these diptera for use as hosts (BARBosa et al. 2004; Mello et al. 2010). Larval therapy requires large quantities of eggs for sterilization (DALLAVECCHIA et al. 2010), which, after hatching, are sent to medical centers and hospitals for immediate use in the debridement of necrotic wounds of different etiologies (SHERman et al. 2000; CAMBAL et al. 2006; AARon et al. 2009; DallaVecchia et al. 2011). Forensic entomology requires comparative studies about the biology of necrophagous Diptera in the laboratory to aid in criminal investigations, as well as to elucidate the postmortem interval (Mello \& Aguiar-Coelho 2009).

Several species of blowflies of the family Calliphoridae exhibit synanthropic behavior, i.e., they are well adapted to the adverse conditions created by humans. The disordered expansion of human housing and changes in local ecosystems has led to the formation of new ecological niches where certain animals are able to adapt and coexist with the products of this process of urbanization. The resulting conditions of poor environmental hygiene, such as human and domestic animal excreta, urban and industrial wastes, garbage dumps, landfills, open cesspools and wastes from street markets represent a serious health risk (PARAllupi et al. 1996; Oliveira et al. 2002), generating high losses for local economies and public health.

Chrysomya megacephala (Fabricius) is a species of blowfly that originated in Africa, the Mediterranean and the Middle East (GAGNé 1981). This species was introduced into Brazil in the 1970 s and today is widely distributed throughout the country in urban areas, where it is most common (MARINHo et al. 2003), as well as rural areas (Singh \& Moore 1985) and even forests (FERrAZ et al. 2010). 
According to D'AlmEIDA \& LimA (1994), a protein diet is fundamental for calliphorids, known popularly as blowflies, not only as food but also for the maturation of their ovarian follicles, which occurs in their tenth stage of development.

Many researchers use beef as protein diet for the uninterrupted breeding of diptera of the family Calliphoridae in the laboratory (GABRE et al. 2005). However, this diet not only increases breeding costs but is also time-consuming for researchers, since it involves cutting the beef into cubes prior to its use. Other substrates for breeding $C$. megacephala have been tested, such as horse meat, fish (sardine), bovine liver, chicken liver, chicken meat, wet dog food, among others (QueIROZ \& MiLwARD-DE-AzEvEDo 1991; Ribeiro \& Milward-DE-AzEvedo 1997; Barbosa et al. 2004; Silva et al. 2008; SousA et al. 2010, Ferraz et al. 2011).

In view of the above, there is an urgent need to establish an insectary for breeding diptera in the laboratory. This would enable studies of their behavior, including an adequate diet to meet their nutritional needs at a low operational cost, and the determination of physical characteristics such as consistency, physiochemical properties such as $\mathrm{pH}$ and osmotic pressure, and biological traits. The final result would be normal individuals with adequate reproductive capacity and longevity for the establishment of a stock colony maintained under high quality control.

The purpose of this study was to evaluate a chicken gizzard diet for breeding $C$. megacephala, analyzing biological aspects such as the body mass of mature larvae, duration of post-embryonic stages (larvae, pupae and newly emerged adults), determination of the time the larvae abandon the diet, their hatching pace, the viability of the larval, pupal and adult stages, normality rate, sex ratio and adult longevity.

\section{MATERIAL AND METHODOS}

The colony of $C$. megacephala was composed of specimens collected in the Zoological Gardens of the State of Rio de Janeiro, RioZoo. The adult insects, which were captured using traps similar to those described by Mello et al. (2007), were taken to the Laboratório de Estudo de Dipteros do Instituto Biomédico da Universidade Federal do Estado do Rio de Janeiro (UNIRIO).

In the laboratory, the insects were subjected to a temperature of $-10^{\circ} \mathrm{C}$ for about three minutes to reduce their metabolic activity, thus enabling their taxonomic identification. The adult individuals were then placed in wooden cages $\left(40 \times 40 \mathrm{~cm}^{2}\right)$ with nylon netting sides and were fed a daily diet consisting of a solution of $50 \%$ honey in $20 \mathrm{~mL}$ of water. As protein for food and egg-laying substrate, one of the cages was provided with $50 \mathrm{~g}$ of beef and the other with $50 \mathrm{~g}$ of chicken gizzard.

In the experimental period, the temperature and relative humidity were recorded using a thermohygrograph, which registered an average temperature of $26^{\circ} \mathrm{C}$ min. $/ 27^{\circ} \mathrm{C}$ max. and relative humidity of $65 \% \mathrm{~min} . / 80 \% \max$.

Forty newly hatched larvae from second-generation females of the colony kept in the laboratory were placed on $100 \mathrm{~g}$ of diet, using a no. 1 brush. The experiment was performed in triplicate for each treatment: beef (control) and chicken gizzard. The beef was cut into cubes of approximately $2 \mathrm{~cm}^{3}$ and the gizzard was used whole. Both diets were fresh, non-frozen. In each treatment, the respective diet was provided in plastic jars (200 g) which were placed in larger containers (500 g) containing $5 \mathrm{~g}$ of sterilized wood shavings spread around their internal circumference, which were then duly identified and closed with nylon netting and elastic bands.

The mass of mature larvae that abandoned the diet was recorded in lots of five larvae, using a semi-analytical balance. The specimens were then placed in test tubes $(20 \times 200 \mathrm{~mm})$ containing $2 \mathrm{~g}$ of sterilized wood shavings to pupate. The test tubes were identified according to each source repetition, and were examined daily, always at 10 o'clock in the morning, until the adults emerged.

After the adults emerged, three replications were made with 10 pairs (male and female), which were isolated in cages made of polyethylene bottles with a volume of one and a half liters, equipped with sides of nylon netting for ventilation. The same procedure was performed for the control diet. The adults were fed a daily diet of a solution of $50 \%$ honey in $5 \mathrm{~mL}$ of water, which was placed in containers $(15 \times 30 \mathrm{~mm})$ inside the cages. These experiments were observed daily.

The Microsoft Excel software program was used to analyze the raw data and create graphics. The results were subjected to an analysis of variance and the means were compared by Tukey's post-hoc test at a $5 \%$ level of significance, using Instat 2, version 2.05a, GraphPad software. Longevity was analyzed using the Kaplan-Meier estimator and Weibull regression. The logrank test was applied to compare differences between the longevity curves, using the R statistical program.

\section{RESULTS}

No significant difference was observed in the mass of mature larvae of mature $C$. megacephala larvae created on the chicken gizzard and beef diets $(\mathrm{p}=0.578)$. However, the average duration of the development of the larval stage $(\mathrm{p}=0.0009)$ was significantly longer in the insects created on the beef diet. The larval and pupal $(\mathrm{p}=0.1314)$ stages and newly emerged adults $(\mathrm{p}=0.5996)$ showed no significant difference as a function of the diets (Table 1).

Table 1. Body mass (mg) and duration, in days, of the post-embryonic development stages of mature Chrysomya megacephala larvae bred on chicken gizzard and beef diets (avg. Temp: $26^{\circ} \mathrm{CMin} . / 27^{\circ} \mathrm{Max}$., avg. Relative Humidity: 65\% Min./80\% Max.)

\begin{tabular}{lcccc}
\hline \multirow{2}{*}{ Diet } & \multicolumn{4}{c}{ Body mass and duration of the stages, in days } \\
\cline { 2 - 5 } & Mass (mg) & Larval & Pupal & Adult \\
\cline { 2 - 5 } & Mean \pm SD & Mean \pm SD & Mean \pm SD & Mean \pm SD \\
\hline Gizzard & $73.3 \mathrm{a} \pm 8.0$ & $3.0 \mathrm{a} \pm 0.08$ & $3.8 \mathrm{a} \pm 0.07$ & $6.8 \mathrm{a} \pm 0.07$ \\
Beef & $72.2 \mathrm{a} \pm 4.5$ & $3.2 \mathrm{~b} \pm 0.01$ & $3.7 \mathrm{a} \pm 0.14$ & $6.8 \mathrm{a} \pm 0.05$ \\
\hline
\end{tabular}

$\mathrm{SD}=$ Standard deviation

Mean values followed by the same letter in the same column do not differ significantly, according to Student's $t$ test, at a $5 \%$ level of significance.

The viability of the larval (97\% and 92\%) and adult (84\% and $69 \%$ ) stages of insects created, respectively, on the gizzard and beef diet was higher with the gizzard diet. In contrast, the viability of the pupal stage (99\% and 100\%) showed similar results for gizzard and beef. There was no deviation in the sex ratio in the two diets, with the gizzard diet showing a ratio of 0.51 and that of beef 0.55 . The sex ratio (SR) was determined as follows: $\mathrm{RS}=$ $\mathrm{F} / \mathrm{M}+\mathrm{F}$, where $\mathrm{F}$ is the number of females and $\mathrm{M}$ is the number of males.

The mature C. megacephala larvae abandoned the two substrates at a similar pace, starting and peaking on the second day of the experiment. The rate of abandonment of the diet on the third day was $1.29 \%$ for gizzard and $\mathbf{1 2 . 0 0 \%}$ for beef, extending up to the fourth day in the case of the control diet, when $0.67 \%$ of larvae abandoned the substrate. With regard to the peak of adult emergence, the gizzard and beef diets were similar, i.e., the diptera emerged from the pupae starting on the sixth day and peaked on the seventh, extending up to the eighth day in the beef diet.

Figure 1 presents the longevity curve estimated by the KaplanMeier nonparametric method and the Weibull regression. In both 
cases, the beef and gizzard diets were considered covariables. According to the Kaplan-Meier estimator, the median longevity of the blowflies bred on the beef diet was 37 days while that of the insects bred on gizzard was 39 days. All the flies bred on beef were dead in 55 days, while those bred on gizzard lived for 60 days. The logrank test was applied to compare the longevity curves and ascertain a possible difference in this parameter. A p-value of 0.63 was obtained at a confidence level of 95\%, leading to the conclusion that there was no difference in the longevity curves of the beef and gizzard diet.

Based on the Weibull regression with a p-value of 0.59 , it was concluded that there was no difference between the diets. The estimates of maximum likelihood for the parameters of shape and scale were 3.34 and 39.13, respectively. The survival curve was of type I, according to REIS \& HADDAD (1997), i.e., the mortality rate increased over time, since the shape parameter was higher than 1 . The mean time estimated by the Weibull regression is, according to Colosimo \& Giolo (2006), a way to ascertain the adequateness of the model based on the graphic created from the estimates obtained by the Kaplan-Meier method versus the estimates obtained by the model. If the adjustment is adequate, it is expected that the curve follow the straight line $\mathrm{x}=\mathrm{y}$.

Figure 2 illustrates the longevity estimated by the Kaplan-Meier method versus the estimates obtained by Weibull regression. Since the curve follows a straight line, the Weibull model is well fitted to the data under study.

To examine the sex of the flies fed on beef substrate, Figure 3 depicts the Kaplan-Meier and Weibull regression estimates for the males and females that were bred on this diet. Based on the logrank test and the p-value of 0.58 , it was concluded that there was no difference between the sexes, which was also found by the Weibull regression with a p-value of 0.77 .

The values of the estimates obtained by the adjustment of the Weibull regression were 2.9 for the shape parameter and 38.5

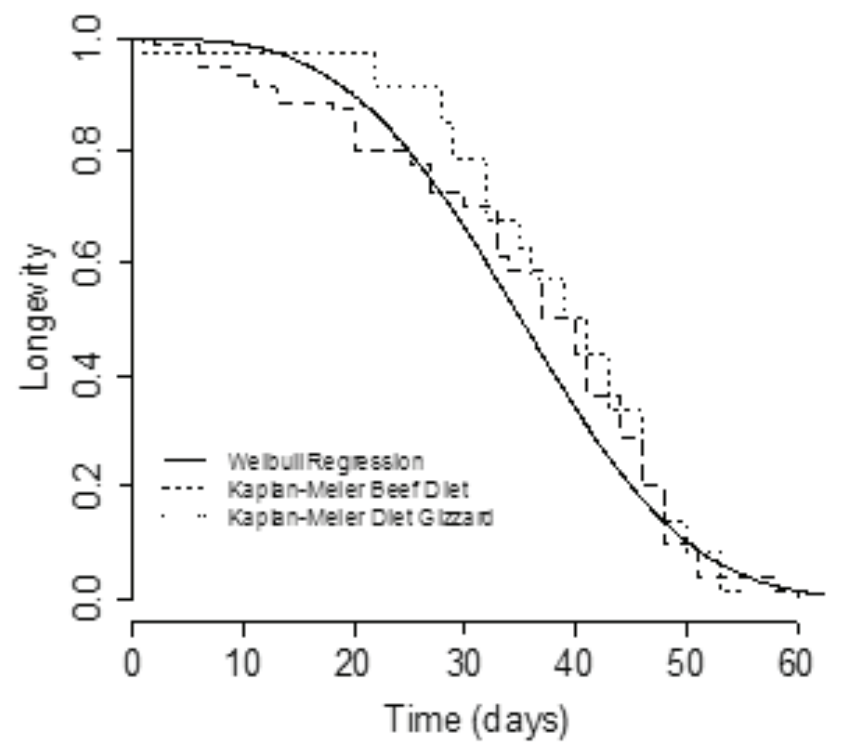

Figure 1. Curves longevity of Chrysomya megacephala estimated by the Kaplan-Meier and Weibull regression adjustment (Temp. Average: $26^{\circ}$ $\mathrm{C}$ min. / $27^{\circ} \mathrm{Max}, \mathrm{RH}$ average: $65 \%$ Min / Max 80\%).

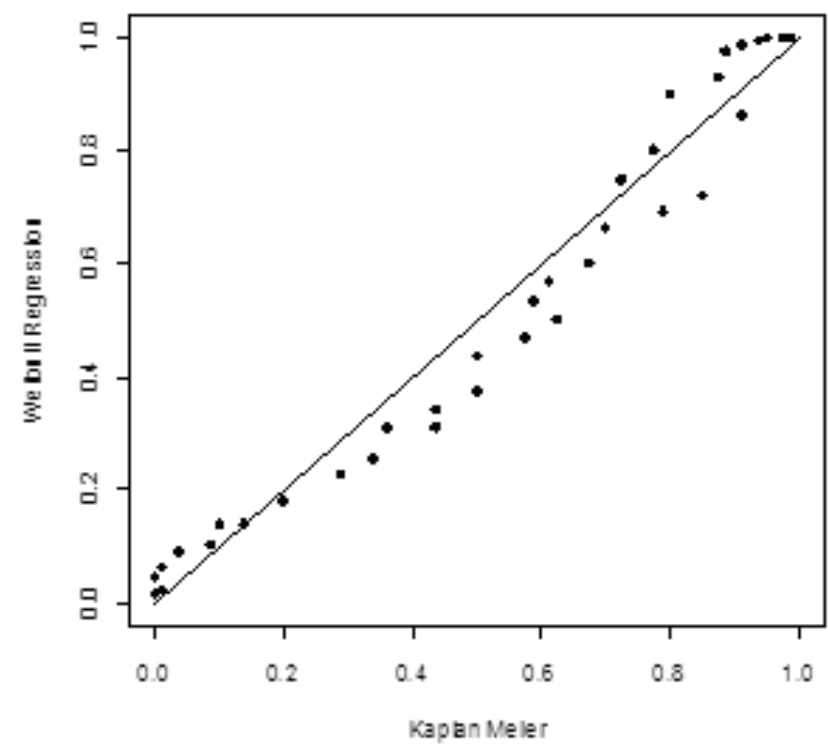

Figure 2 - Longevity of Chrysomya megacephala estimated by KaplanMeier versus Weibull regression (T. average: $26^{\circ} \mathrm{C}$ Min / Max $27^{\circ}, \mathrm{RH}$ average: $65 \%$ Min / Max 80\%).
Beef Diet - Female

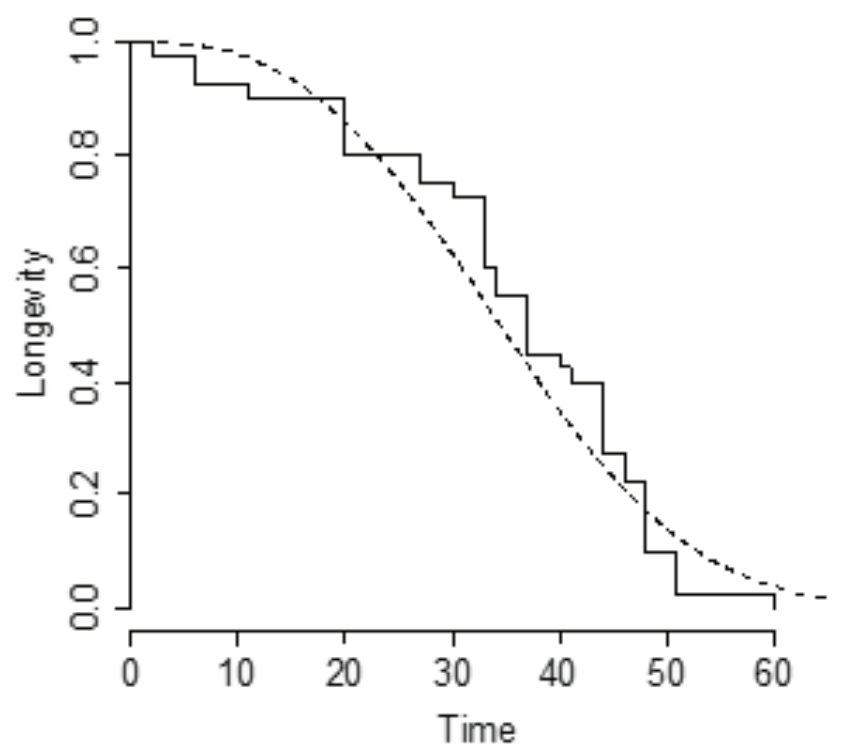

Beef Diet - Male

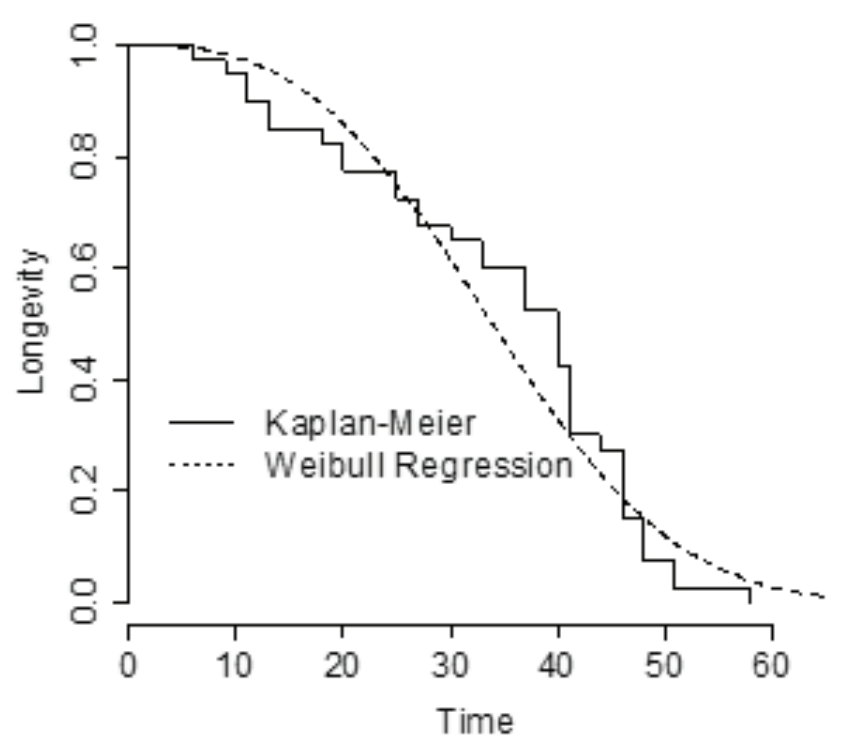

Figure 3. Longevity of Chrysomya megacephala estimated by Kaplan-Meier and Weibull regression for females and males eared in meat diet (T. average: $26^{\circ} \mathrm{Cmin}$. / $27^{\circ} \mathrm{Max}, \mathrm{RH}$ average: $65 \%$ Min / Max 80\%). 

for the scale parameter, indicating that the survival curve was of type 1 for the males bred on the beef diet, with an estimated mean longevity of 34.3 days. The values estimated for the females were 2.8 and 39.3 for the shape and scale parameters, respectively, and the estimated mean longevity was 34.98.

Figure 4 illustrates the Kaplan-Meier and Weibull regression estimates for the males and females bred on chicken gizzard.
The logrank test indicated no difference between the sexes, with a p-value of 0.87 , and the same was concluded by the Weibull regression with a p-value of 0.88 . The estimated mean longevity of both males and females bred on gizzard was 37.7 days. The shape and scale parameters for the males were 4.1 and 41.6, respectively and for the females 3.8 and 44.8 . In both cases, the survival curve was the type 1 curve.
Beef Gizzard - Female

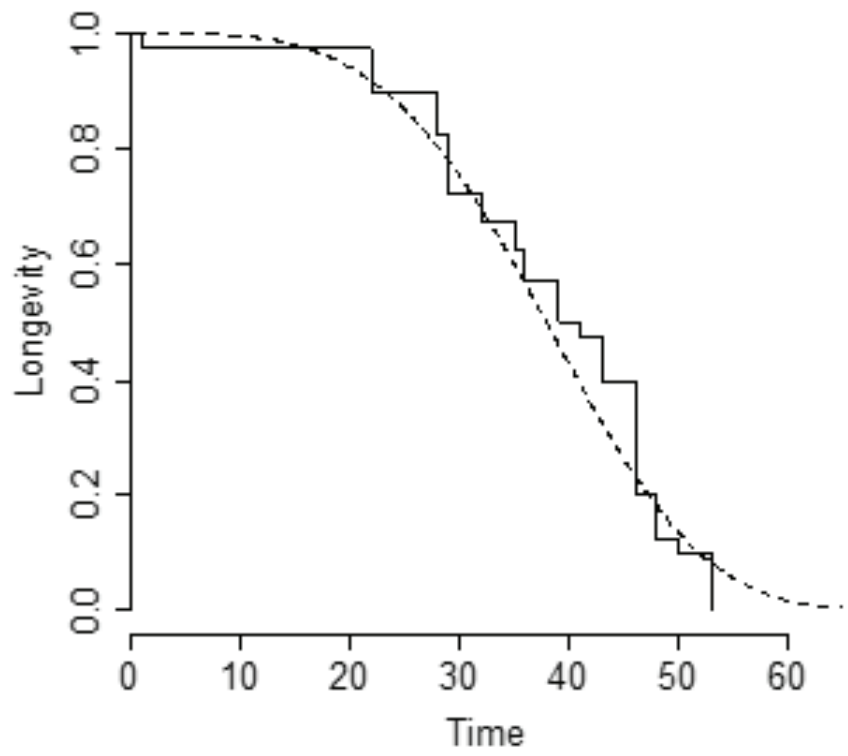

Diet Giz zard - Male

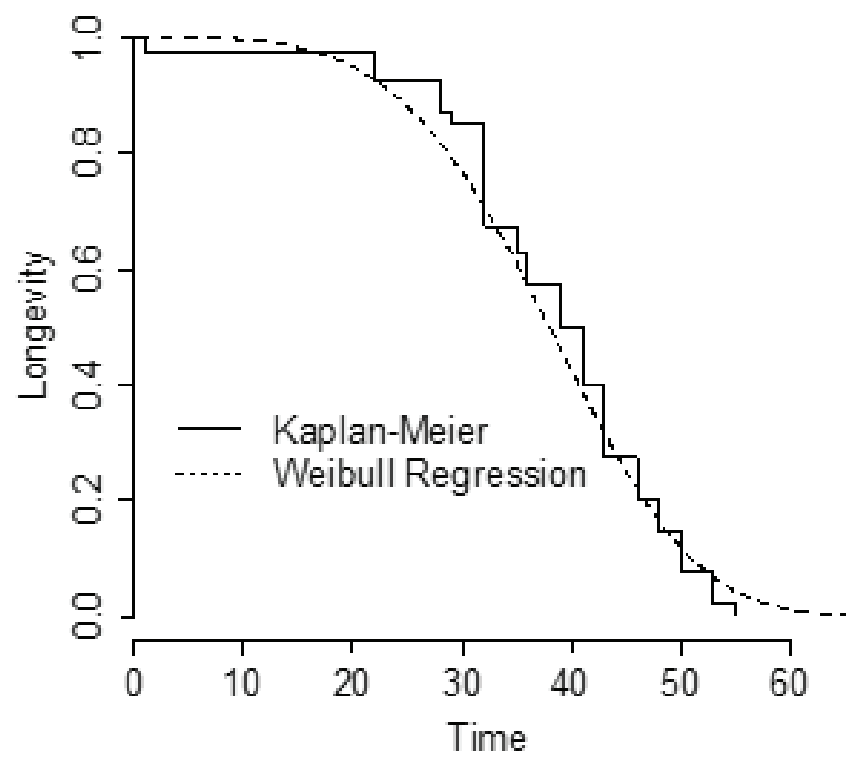

Figure 4. Longevity of Chrysomya megacephala estimated by Kaplan-Meier and Weibull regression for females and males reared on a diet gizzard (T. average: $26^{\circ} \mathrm{Cmin}$. / $27^{\circ} \mathrm{Max}$, RH average: 65\% Min / Max 80\%).

\section{DISCUSSION}

Several authors have tested protein-based diets (Table 2) for maintaining their colonies in the laboratory, but the most commonly used natural diet for creation C. megacephala larvae is beef. However, not only is the cost of beef on the rise but this substrate also requires chopping into cubes of approximately $2 \mathrm{~cm}^{3}$, storing in plastic bags, which are then placed in plastic containers for freezing, a procedure that is work-intensive and time-consuming (QueIroz \& Milward-DE-AzEvedo 1991; Gabre et al. 2005).

A comparison of the nutritional value of beef (brisket) and chicken gizzard indicated that, according to information from producers, $100 \mathrm{~g}$ of the products contain the same nutrients, and that these diets differ only in the number of kcal, grams or milligrams. According to this analysis, the nutritional information on beef and gizzard, respectively, is as follows: calories (150 Kcal and 92 Kcal), proteins (16 g and $21 \mathrm{~g}$ ), total fats ( $2 \mathrm{~g}$ and $6 \mathrm{~g}$ ), saturated fats (0.5 g and $2 \mathrm{~g}$ ), cholesterol (97 $\mathrm{mg}$ and $125 \mathrm{mg}$ ), calcium (8 $\mathrm{mg}$ and $12 \mathrm{mg}$ ), iron (1.95 $\mathrm{mg}$ and $3.2 \mathrm{mg}$ )) and sodium (82 mg and $130 \mathrm{mg}$ ). However, this difference did not exert a negative effect on the development of the diptera. It was found that the duration of the larval stage of the insects created on beef was longer than on gizzard. This reflects the pace of abandonment of the substrate, which extended to the fourth day after the beginning of the experiment for the insects bred on beef, while the majority (98.71\%) of larvae bred on gizzard abandoned their diet on the second day, indicating a greater homogeneity in the development of the insects bred on the tested diet. PARRA (2001) states that it is important to provide a diet for insects that is attractive in terms of toughness, texture, homogeneity and water. Some authors consider that faster larval development may be advantageous for the survival of insects, since it enables them to reach maturity more rapidly (AguiAR-CoELHo \& MiLWARD-DE-AZEvEdo 1998).
SANTos et al. (1996) created C. megacephala larvae on a diet of sardines stored previously for 2 and 24 hours at $30^{\circ} \mathrm{C}$, and reported that the peak of abandonment of the substrate occurred on the third day, which is later than that recorded in the present study, although the average temperature was lower $\left(26^{\circ} \mathrm{C}\right.$ min. $/ 27^{\circ} \mathrm{C}$ max.), suggesting that the diet may have influenced this biological parameter.

The difference observed in the duration of the larval stages did not interfere in the body mass gain of the immature insects, which was similar on the two diets. The weight of immature insects is reflected directly in the development of adult insects, such as size, survival rate, dispersion and reproductive capacity (D’Almeida \& Oliveira 2002).

The total longevity (males and females) of the insects cread on the two diets did not differ significantly. A separate analysis of the females and males revealed no difference between the sexes, and their expected longevity was very similar. In their experiment, BARBosa et al. (2004) tested an alternative diet of wet dog food (Pedigree $\AA$ ) and found that females bred on the beef diet lived longer. GABRE et al. (2005) created a life table of $C$. megacephala cread on beef and also observed that the longevity of females exceeded that of males.

Sousa et al. (2010) tested chicken liver as a diet for this species and found that the insects presented significantly lower viability in the larval stages and newly emerged adults when compared with the control diet. However, in the present study, the tested chicken gizzard diet proved superior to beef from the standpoint of two parameters: viability of larvae and of newly emerged adults. The difference in pupae viability was minimal (99\% gizzard and 100\% beef), indicating that chicken gizzard can be a cheaper alternative diet that is as efficient as beef for breeding these blowflies.

The sex ratio on both diets was close to $50 \%$, a pattern considered 
Table 2. Diets used for breeding Diptera in the laboratory.

\begin{tabular}{|c|c|c|c|c|}
\hline Family & Species & Diet & Reference & Year \\
\hline \multirow[t]{13}{*}{ Calliphoridae } & \multirow[t]{4}{*}{ Chrysomya albiceps (Wiedemann } & $\begin{array}{l}\text { Raw bovine liver, muscle and rumen, and } \\
\text { chicken heart }\end{array}$ & Estrada et al. & 2009 \\
\hline & & Horse meat & Ribeiro \& MilwaRd-DE-AZEvedo & 1997 \\
\hline & & Putrefied horse meat & Aguiar-Coelho et al. & 1995 \\
\hline & & Beef & QueIroZ \& MilWARD-DE-AZEvedo & 1991 \\
\hline & \multirow{5}{*}{$\begin{array}{l}\text { Chrysomya megacephala } \\
\text { (Fabricius) }\end{array}$} & Fowl liver & Sousa et al. & 2010 \\
\hline & & $\begin{array}{l}\text { Albumin, vegetable oil, vitamins, mineral } \\
\text { salts, agar, nipagin and distilled water }\end{array}$ & Mendonça et al. & 2009 \\
\hline & & Beef & GABRE et al. & 2005 \\
\hline & & Wet dog food (Pedigree $\AA$ ) & BARBOSA et al. & 2004 \\
\hline & & Fish & ESSER & 1990 \\
\hline & Cochiomyia macellaria (Fabricius) & Putrefied horse meat & Aguiar-Coelho et al. & \\
\hline & \multirow[t]{2}{*}{ Lucilia cuprina (Wiedemann) } & $\begin{array}{l}\text { Horse meat, formaldehyde, beer yeast, } \\
\text { calcium proteinate, Wesson salts, agar } \\
\text { and chicken eggs }\end{array}$ & Cunha e Silva et al. & 1994 \\
\hline & & $\begin{array}{l}\text { Horse meat in different stages of } \\
\text { putrefaction }\end{array}$ & PAES et al. & 2000 \\
\hline & Phaenicia sericata (Meigen) & Bovine liver & Silva et al. & 2008 \\
\hline Sarcophagidae & $\begin{array}{l}\text { Ravinia belforti } \\
\text { (Prado \& Fonseca) }\end{array}$ & Ground beef, bovine liver, dog biscuits & KAMAL & 1958 \\
\hline Muscidae & Musca domestica (Linnaeus) & $\begin{array}{l}\text { Wheat bran, alfalfa meal, Purina grains } \\
\text { and beer }\end{array}$ & GREENBERG & 1954 \\
\hline
\end{tabular}

normal (EsSER 1990). The same ratio was reported by MILwARDDE-AzEvedo et al. (2000) upon comparing oligidic diets, and by GABRE et al. (2005) in their experiment with beef.

An aspect that must be considered when choosing a diet is the cost-benefit ratio (CHAUndhury et al. 2000). A kilo of brisket is on average $20 \%$ more expensive than a kilo of chicken gizzard. Another advantage is that this substrate can be used whole, which facilitates the work of researchers in maintaining large stocks of Diptera and in the storage of the diet, reducing the time spent on its preparation.

The findings of this study will enable more efficient and cheaper large-scale production of these insects for use in maggot therapy, in studies of environmental control with parasite pupae, in forensic entomology, and as an aid for other scientists such as herpetologists, entomologists, aquarists, frog breeders, and others.

The chicken gizzard diet was considered adequate for breeding C. megacephala in the laboratory and is recommended as an alternative diet to beef. The biological parameters of body mass of mature larvae, duration of the larval, pupal stages to newly emerged adults did not differ significantly from the control (beef), while the viability of the larval stages and newly emerged adults was higher for adults bred on the gizzard diet. The longevity of adults bred on the gizzard diet was also higher.

\section{ACKNOWLEDGMENTS}

The authors gratefully acknowledge the Federal University of Rio de Janeiro State - UNIRIO, CNPq- PIBIC, FAPERJ, Capes and FINEP (Brazil) for their financial support of the Laboratory for Diptera Studies.

\section{REFERENCES}

Aaron, G.P., W.A. Nazni, H.L. Lee, M.A. Ariff, M. Saranum, A.S Naicker \& O. Zulkiflee, 2009. Maggot debridement Therapy with Lucilia cuprina: a comparison with convencional desbridement in diabetc foot ulcers. International Wound Journal, 6: 39-46.

Aguiar-Coelho, V.M., M.M.C. Queiroz \& E.M.V. Milward-de-
Azevedo, 1995. Associações entre larvas de Cochiomya macellaria (Fabricius) e Chrysomya albiceps (Wiedemann) (Diptera, Calliphoridae) em condições experimentais. Revista Brasileira de Zoologia, 4: 983-990.

Aguiar-Coelho, V.M. \& E.M.V. Milward-de-Azevedo, 1998. Combined rearing of Cochliomyia macellaria (Fabricius), Chrysomya megacephala (Fabricius) e Chrysomya albiceps (Wiedemann) (Diptera: Calliphoridae) under laboratory conditions. Journal of Applied Entomology, 122: 551-554.

Barbosa, L.S., D.M.L. Jesus \& V.M. Aguiar-Coelho, 2004. Longevidade e capacidade reprodutiva de casais agrupados de Chrysomya megacephala (Fabricius, 1794) (Diptera: Calliphoridae) oriundos de larvas criadas em dieta natural e oligídica. Revista Brasileira de Zoociências, 6: 207-217.

Cambal, M., P. Labas, M. Kozanek, P. Takac \& Z. Krumpalova, 2006. Maggot debridement therapy. Bratislava Medical Journal, 107: 442-444.

Chaudhury, M.F., L.A. Alvarez \& L.L. Velasquez, 2000. A new meatless diet for adult screwworm (Diptera: Calliphoridae). Journal of Economic Entomology, 93: 1398-1401.

Colosimo, E.A. \& S.R. Giolo, 2006. Análise de sobrevivência aplicada, São Paulo: Edgard Blücher.

Cristino, A.S., F.M.F. Nune, A.R. Barchuk, V.M. Aguiar -Coelho, Z.L.P. Simões \& M.M. Bitondi, 2010. Organization, evolution and transcriptional profile of hexamerin genes of the parasitic wasp Nasonia vitripennis (Hymenoptera: Pteromalidae). Insect Molecular Biology, 19: 137-147.

Cunha-e-Silva, S.L. \& E.M.V. Milward-de-Azevedo, 1994. Estudo comparado de desenvolvimento pós-embrionário de Cochliomya macellaria (Fabricius) (Diptera: Calliphoridae) em duas dietas à base de carne, em laboratório. Revista Brasileira de Zoologia, 11: 659-668.

Dallavecchia, L.D., G.R. Silva Filho, A.M.N. Figueiredo \& M.V. Aguiar-Coelho, 2011. Esterilização da superfície dos ovos de Chrysomya megacephala (Fabricius, 1794) para utilização em biodesbridamento. Journal of Research: Fundamental Care (Online) (Ed.asupl. 1): 4.,Available in: < http://dx.doi. org/10.9789/2175-5361.2010.voio.\%25p >.

Dallavecchia, D.L., B.N. Proença, V.M.A. Coelho, 2010. Biotherapy: an efficient alternative for the treatment of skin lesions. Journal of Research: Fundamental Care (Online), 3: 2071-2079. Available in: <http://www.seer.unirio.br/index. 
$\mathrm{php} /$ cuidadofundamental/article/view/1283>.

d'Almeida, J.M. \& S.F. Lima, 1994. Atratividade de diferentes iscas e sua relação com as fases de desenvolvimento ovariano em Calllphoridae e Sarcophagidae (insecta, diptera). Revista Brasileira de Zoologia, 2: 177-186.

d'Almeida, J.M. \& V.C. Oliveira, 2002. Dietas artificiais para a criação em laboratório de Chrysomya (C. megacephala, $C$. albiceps e C. putoria) (Diptera: Calliphoridae)._Entomología y Vectores, 9: 79-91.

Esser, J.R., 1990. Factors influencing oviposition, larval growth and mortality in Chrysomya megacephala (Diptera: Calliphoridae), a pest of salted dried fish in south-east Asia. Bulletin of Entomological Research, 80: 369-376.

Estrada, D.A., M.D. Grella, P.J. Thyssen \& A.X. Linhares, 2009. Taxa de desenvolvimento de Chrysomya albiceps (Wiedemann) (Diptera: Calliphoridae) em dieta artificial acrescida de tecido animal para uso forense. Neotropical Entomology, 38: 203-207. Available in: <http://dx.doi. org/10.1590/S1519-566X2009000200006 >.

Ferraz, A.C.P., B.Q. Gadelha, V.M. Aguiar-Coelho, 2010. Análise Faunística de Califorídeos (Diptera) da Reserva Biológica do Tinguá, Nova Iguaçu, Rio de Janeiro. Revista Brasileira de Entomologia, 53: 620-628. Available in: <http://dx.doi. org/10.1590/Soo85-56262009000400012>.

Ferraz, A.C.P., D.B. Bosisio, D.D \& Aguiar, V.M.A, 2011. Dieta para larvas de Chrysomya megacephala, Chrysomya putoria e Cochliomyia macellaria (Diptera: Calliphoridae). EntomoBrasilis, 4: 125-129. Available in: <http://dx.doi. org/10.12741/ebrasilis.v4i3.138>.

Ferraz, A.C.P., D.L. Dallavecchia, D.C. da Silva, R.P. Carvalho, R.G. Silva Filho, V.M. Aguiar-Coelho, 2012. Alternative diets for Chrysomya putoria, an Old World screwworm fly. Journal of Insect Science, 12: 37. Available in: <http://jinsectscience. oxfordjournals.org/content/jis/12/1/43.full.pdf $>$.

Gabre, R.M., F.K. Adham \& H. Chi, 2005. Life table of Crysomya megacephala (Fabricius) (Diptera: Calliphoridae). Acta oecologica, 27:179-183. Availablein: $<$ http://140.120.197.173/ Ecology/papers/gabre-paper.pdf $>$.

Gagné, R.J., 1981. Chrysomya spp., old Word blowfiles (Diptera: Calliphoridae), Recently established in the americas. Annals of the Entomological Society of America, 27: 21-22.

Greenberg, B. 1954. A method for the sterile culture of housefly larvae, Musca domestica L. The Canadian Entomologist, 86: 527-528.

Marinho, C.R., A.C.G. Azevedo \& V.M.A. Coelho, 2003. Diversidade de Califorídeos (Diptera: Calliphoridae) em área urbana, Rio de Janeiro. Entomologia y Vectores, 10: 185199.

Mello, R.S., M.M.C. Queiroz \& V.M. Aguiar-Coelho, 2007. Population fluctuations of calliphorids species (Diptera, Calliphoridae) in the Biological Reserve of Tinguá, state of Rio de Janeiro, Brazil. Iheringia - Série Zoológica 97: 1-5. Available in: <http://dx.doi.org/10.1590/Soo7347212007000400019>.

Mello, R.S., G.E.M. Borja, V.M.A. Coelho, 2010. Effects on Microhymenopteran Progeny of Different Host Exposure Periods (Chrysomya megacephala, Calliphoridae) to the Parasitoid Wasp Nasonia vitripennis (Hymenoptera: Pteromalidae). Brazilian Archives of Biology and Technology, 53: 77-85. Available in: <http://dx.doi.org/10.1590/S151689132010000100010>.

Mello, R.S. \& V.M. Aguiar-Coelho, 2009. Durations of immature stage development period of Nasonia vitripennis (Walker) (Hymenoptera: Pteromalidae) under laboratory conditions: implications for forensic entomology. Parasitology Research, 104: 411-418. Available in: <http://dx.doi.org/10.1007/ s00436-008-1213-Z>.

Mendonça, P.M., M.M.C. Queiroz \& J.M. d'Almeida, 2009. Rearing Chrysomya megacephala on Artificial Diets Composed of Varing Concentrations of Albumin. Brazilian Archives of Biology and Technology 52: 421-426. Disponível em:
<http://dx.doi.org/10.1590/S1516-89132009000200020>.

Milward-de-Azevedo, E.M.V., V.M. Carraro, C.R.P. Carvalho, S.V.P. BrandoliniI, E.G.M. Ribeiro, A.T.S. Almeida \& M.G.R. Amorium, 200o. Criação de Chrysomya (Fabricius) (Diptera: Calliphoridae) em dietas comerciais: abordagem preliminar. Revista Brasileira de Medicina Veterinária, 22: 113-116.

Oliveira, V.C., R.P. Mello \& J.M. d`Almeida, 2002. Dípteros muscóides como vetores mecânicos de ovos de helmintos em Jardim Zoológico. Revista de Saúde Pública, 36: 614620. Available in: <http://dx.doi.org/10.1590/Soo3489102002000600011>.

Paes, M.J., L.G. Brito, M.C. Branco \& G.E. Borja-Moya, 2000. Desenvolvimento pós-embrionário de Lucilia cuprina (Wied, 1830) (Diptera: Calliphoridae), criada em dieta a base de carne eqüina em diferentes estágios de putrefação. Parasitologia el Dia, 24: 102-108. Available in: <http://dx.doi.org/10.4067/ So716-07202000000300006>.

Paraluppi, N.D., J.C. Vasconcelos, J.S. Aquino, E.G. Castellon \& M.S.B. Silva, 1996. Calliphoridae (Diptera) in Manaus: IV Bacteria isolated from blowflies collected in street markets. Acta Amazônica, 26: 93-96.

Parra, J.R.P., 2001. Técnicas de criação de insetos para programas de controle biológico, $6^{\circ}$ edição. Piracicaba, ESALQ/FEALQ, $134 \mathrm{p}$.

Queiroz, M.M.C. \& E.M.V. Milward-de-Azevedo, 1991. Técnicas de criação e alguns aspectos da biologia de Chrysomya albiceps (Wiedemann) (Diptera, Calliphoridae) em condições de laboratório. Revista Brasileira de Zoologia, 8: 75-84.

Reis, P.R., M.L. Haddad, 1997. Distribuição de Weibull como Modelo de Sobrevivência de Iphiseiodes zuluagai Demark e Muma (Acari: Phytoseiidae). Anais da Sociedade Entomológica do Brasil, 26: 3 441-444.

Ribeiro, R.C., E.M.V. Milward-de-Azevedo, 1997. Dietas Naturais de criação de C. albiceps (Diptera: Calliphoridae): Estudo comparado. Revista Ciência Rural, 27: 641-644.

Santos, M.B., C. Martins \& E.M.V. Milward-de-Azevedo, 1996. Desenvolvimento pós-embrionário de Chrysomya megacephala (Fabricius) (Diptera: Calliphoridae) criada em dieta a base de sardinha previamente exposta, por diferentes períodos, à condições controladas. Brazilian Archives of Biology and Technology, 39: 799-805.

Sherman, R.A., M.J. Hall \& S. Thomas, 2000. Medicinal maggots: an ancient remedy for some contemporary afflictions. Annual Review of Entomology, 45: 55-81. Available in: <http:// dx.doi.org/10.1146/annurev.ento.45.1.55>.

Sherman, R.A, 2009. Maggot Therapy Takes Us Back to the Future of Wound Care: New and Improved Maggot Therapy for the 21st Century. Journal of Diabetes Science and Technology, 3 : 336-344. Available in: <http://www.ncbi.nlm.nih.gov/pmc/ articles/PMC2771513>.

Silva, A.S., R.A. Zanatte \& S.G. Monteiro, 2008. Biologia da mosca Phaenicia sericata em diferentes substratos. Revista Brasileira de Parasitologia Veterinária, 17: 63-66. Available in: <http://www.scielo.br/pdf/rbpv/v17n2/o1.pdf >.

Singh, P. \& R.F Moore, 1985. Handbook of insect rearing. Elsevier Science, Publishers, New York, USA, 474p.

Sousa, A.G.P., A.C.P. Ferraz, A.L.O. Nascimento \& V.M. AguiarCoelho, 2010. Alternative natural diet for the creation of immature oriental latrine flies under controlled conditions. Revista Brasileira de Zoologia, 12: 133-140. Available in: $<$ http://zoociencias.ufjf.emnuvens.com.br/zoociencias/ article/viewFile/1566/1133>.

\section{Received in: 06/28/2014}

Accepted in: 12/20/2014 


\section{Suggested citation:}

Dallavecchia, D.L., A.C.P. Ferraz, G.S. de Miranda, A.S. da Silva \& V. Magalhães-de-Aguiar, 2015. Comparative Study Between Chicken Gizzards and Beef as Diets and its Influences on the Post-Embryonic Development and Longevity of Chrysomya megacephala (Fabricius) (Diptera:

Calliphoridae). EntomoBrasilis, 8 (1): 17-23.

Available in: doi:10.12741/ebrasilis.v8i1.454
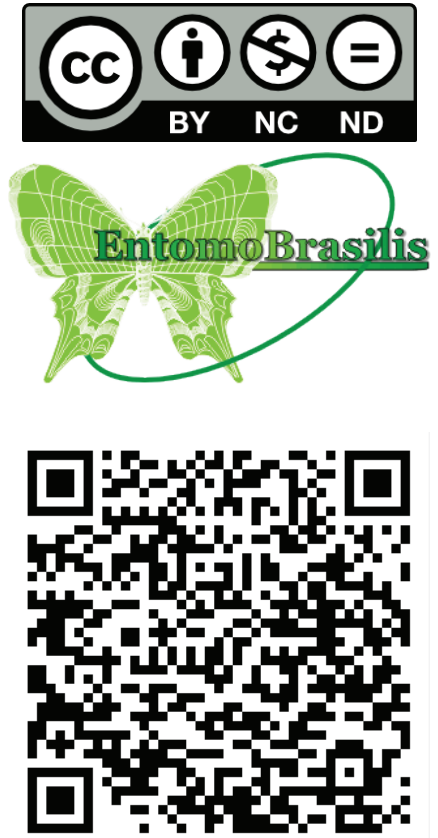